\title{
Equality of arms, impartiality of the judiciary and the role of the parties in the pre-trial inquiry: the perspective of Italian criminal justice
}

Paridade de armas, imparcialidade do Judiciário e o papel das partes na investigação preliminar: a perspectiva da justiça criminal italiana

Stefano Ruggeri ${ }^{1}$

Università degli Studi di Messina/Itália

steruggeri@unime.it

https://orcid.org/0000-0003-2684-3340

\begin{abstract}
The analysis of the prosecutorial inquiry in Italian criminal proceedings displays a complex scenario. In spite of the progressive enhancement of participatory rights of private parties, the overwhelming role of the investigative authorities does not set the necessary conditions for effective equality of arms, while largely frustrating the tasks of the judiciary. To a great extent, the maintenance of several decision-making and coercive powers of the public prosecutor still largely reflect the old conception of an independent body of justice. Even though the individuals involved in the prosecutorial inquiry are ensured participation in a number of police and prosecutorial investigations, legal assistance often lacks effectiveness, and the possibilities of defence lawyers conducting autonomous investigations are scant and only achieve a formal level of par condicio. Certainly, this set-up cannot be justified in a human rights-oriented model of criminal justice. De lege ferenda, the enhancement of the tasks of competent judge for the pre-trial inquiry, who under Italian law is not an investigative magistrate but is called upon to ensure the proper fulfilment of procedural safeguards, appears to constitute today the best alternative to one-sided investigations and the dominant role of the investigative authorities.
\end{abstract}

1 Professor associado de direito processual penal italiano e justiça penal europeia na Universidade de Messina/Itália. Doutor em Direito pela Scuola Superiore Sant'Anna de Pisa/Itália. 
KEY-wORDs: Equality of arms; judicial impartiality; pre-trial inquiry; Italian criminal justice.

Resumo: A análise da investigação pelo Ministério Público no processo penal italiano apresenta um cenário complexo. Apesar do aumento progressivo dos direitos de participação das partes, o papel imenso das autoridades investigativas não determina as condições para a efetividade da paridade de armas, e também prejudica amplamente as tarefas do julgador. Em grande medida, a conservação de vários poderes decisórios e coercitivos do Ministério Público ainda refletem a antiga concepção de um independente membro de Justiça. Ainda que os indivíduos envolvidos na investigação ministerial possam participar em alguns atos policiais e do Ministério Público, a defesa técnica em muitas vezes carece de efetividade, e as possibilidades de investigações autônomas por advogados de defesa são limitadas e somente determinam uma igualdade em nível formal. Certamente, esse cenário não pode ser justificado em um modelo de justiça criminal orientado por direitos humanos. De lege ferenda, o aumento das tarefas do juiz competente para a investigação preliminar, que sistema italiano de justiça penal não é um juiz instrutor, mas um juiz de garantias, mostra-se atualmente como a melhor alternativa em relação a investigações unilaterais e o papel dominante de autoridades investigativas.

Palavras-chave: Paridade de armas; imparcialidade judicial; investigação preliminar; justiça criminal italiana.

\section{INTRODUCTION}

Italian criminal justice has long been characterised by the strong tendency to bring forward the ascertainment of facts prior to the trial phase. Under the 1930 code of criminal procedure (the so-called 'Rocco code'), fact-finding was largely based on the information gathered by the competent bodies for the pre-trial stages. In particular, the intermediate stage (istruzione), headed either by an investigating magistrate or the public prosecutor, ${ }^{2}$ primarily aimed at the collection of evidence for the

2 Investigative judges headed a formal inquiry (istruzione formale), whereas prosecutors an interim one (istruzione sommaria). 
purposes of the trial decisions. ${ }^{3}$ This set-up had considerable repercussions on a number of fundamental rights of the individuals involved in criminal proceedings. Not only had private parties very limited room in the prosecutorial inquiries and the evidence-gathering activities conducted by the investigative magistrate, but furthermore the accused was normally remanded into custody after the institution of istruzione, being therefore deprived of the right to take part in criminal proceedings as a free person. ${ }^{4}$ The inevitable imbalance between the defendant and the competent authority for evidence gathering at the pre-trial stages was further aggravated in the trial, on two main grounds. Firstly, the trial judges could make full use of the information collected by investigative bodies and law enforcement authorities. Secondly, the defence could only give indirect contribution to the taking of oral evidence in open court, since depending on the types of the proceedings, witnesses were examined by either the president of the trial court or by a district court judge (pretore). ${ }^{5}$

Since the beginning of the 1960s, legal scholarship strongly criticised this criminal justice system, particularly the prosecutorial inquiry, which, though initially conceived as an exception to the ordinary judicial inquiry, soon gained ground in practice. There was little doubt that this set-up turned out to frustrate both the possibility of impartial fact-finding and the accused's right to be heard by an independent body. ${ }^{6}$ Constitutional case-law also played an important role in the enhancement of defence rights in the pre-trial phases. However, this model was long tolerated on several grounds, mainly because the public prosecutor, forming part of the judiciary, is under Italian law an independent body of justice (organo

3 Siracusano. Istruzione del processo penale, pp. $166 \mathrm{ff}$.

4 The inclusion of the rules on both arrest and remand detention into the systematic structure of the 1930 code at the beginning of the Book concerned with the intermediate phase was clearly in line with the typically inquisitorial appreciation of pre-trial custody as the most appropriate means of forcefully achieving the collaboration (if not the confession) of the defendant, who was also viewed as an instrument for the success of the criminal inquiries rather than a right holder. Cf. Marzaduri. Misure cautelari personali, p. 61.

5 Art. 440 of the 1930 code.

6 For strong criticisms see, in particular, Cordero. Ideologie del processo penale, pp. $3 \mathrm{ff}$. 
di giustizia). ${ }^{7}$ Yet it was difficult to understand how fact-finding could be deemed truly independent, if the same authority that charged defendants with a criminal offence and remanded them into custody was also empowered to collect incriminating evidence against them. Similar concerns could be raised in relation to the istruzione headed by the investigative magistrate, who not only had considerable coercive powers, but could also autonomously initiate a criminal prosecution in cases of rejection of the prosecutor's request for discontinuance of the proceedings.

It took more than two more decades, however, before Italian lawmakers reformed this legislative set-up. The strong adversarial inspiration of the 1988 codification $^{8}$ (the so-called 'Vassalli code') led the Italian legislature to depart from the previous model of pre-trial inquiries. The public prosecutorial office was deprived of some coercive powers, as pre-trial detention and further restrictions on freedom could only ordered by a judge. Moreover, both the police and the prosecutor could no longer gather evidence with a view to a guilty verdict. Thus, pursuant to a new general exclusionary rule, the trial judges were precluded access to the information collected in the pre-trial stages, which was not to be included into the trial file but into the prosecutorial file that was not at the disposal of the decision-makers. ${ }^{9}$ Along with the reduction of the law enforcement and evidence-gathering powers of the prosecutorial authority, the 1988 code abolished the old investigative magistrate, replaced through a new judicial body, namely a competent judge for the pre-trial inquiry (giudice per le indagini preliminari). Unlike the investigative magistrate, this judge was intended to be an independent authority with the main task of ensuring respect for procedural safeguards in the pre-trial stages, without any power to indict the accused and to gather evidence on his own. ${ }^{10}$

7 See Art. 73 of Royal Decree 12/1941 (statute on the organisation of the judiciary). Critical remarks on this concept were formulated by Chiavario. Il pubblico ministero organo di giustizia?, pp. $714 \mathrm{ff}$.

8 Article 2(1) of the Delegation Law for the new code of criminal procedure (Law 81/1987) contained an explicit reference to the requirement that the drafters of the new codification fulfil the principles of an adversarial model of criminal justice.

9 See Arts. 431 and 433 CCP.

10 On this new judge see the comprehensive analysis of Ruggieri. La giurisdizione di garanzia nelle indagini preliminari. 
A look at the developments that have taken place over almost three decades, however, reveals the enormous difficulties that both Italian courts and the lawmakers encountered to avoid a dangerous return to the mixed system of inquisitorial tradition, while fulfilling the new challenges posed by the case-law of the Strasbourg Court of human rights, ${ }^{11}$ as well as by EU law. This study examines the milestones in the evolution of Italian criminal justice over recent years. While highlighting the steps forward made by the current codification, I shall also analyse the shortcomings of the original model of a prosecutorial inquiry headed by an impartial body of justice, as well as the subsequent developments that occurred in both legislation and case-law, which have deeply altered the trade-offs of the prosecutorial investigation. To this end, I shall firstly examine a preliminary issue, namely whether and to what extent the par condicio principle and the right to be tried before an independent tribunal apply to pre-trial phases in criminal proceedings.

\section{The GUARANTEE OF AN IMPARTIAL JUDGE, THE PRINCIPLE OF CONTRADICTOIRE AND THE EQUALITY OF ARMS IN THE PRE-TRIAL INQUIRY UNDER THE EUROPEAN CONVENTION AND IN THE CONSTITUTIONAL MODEL OF A FAIR TRIAL}

Whereas international human rights law and the constitutional law of several European countries generally acknowledge the right to be tried before an independent and impartial court in criminal matters, the principle of equality of arms is not widely recognised with specific regard to criminal proceedings. The Pact of San José is quite unique among other international human rights charters, in that it expressly grants the person charged with a criminal offence a set of minimum due process safeguards "with full equality". ${ }^{12}$ The European Convention on Human Rights, instead,

11 The aforementioned Article 2(1) of Law 81/1987 also required the drafters of the new code to comply with the provisions set forth by the international conventions ratified by Italy, regarding the rights of the individuals involved in criminal proceedings, a requirement that explicitly aimed at orienting the current codification towards the standards of protection acknowledged by the European Convention and further developed by Strasbourg case-law.

12 Art. 8(2) ACHR. 
does not explicitly enshrine the principle of par condicio in criminal matters. There is little doubt, however, that the fundamental guarantee of equal treatment is of the utmost relevance in the model of a fair trial under the Rome Convention. The case-law of the Strasbourg Court has confirmed this assumption on various occasions by recognising that "the right to an adversarial process, as required by Article 6 of the Convention, means that both the prosecution and to the defense must be given the opportunity to have knowledge of and comment on the observations filed and the evidence adduced by the other party". ${ }^{13}$ On close examination, this conclusion does not contradict the spirit of the Convention, which, although not enabling prosecutors to claim state-related interests before the Strasbourg institutions, ${ }^{14}$ does not ensure defendants the right to be heard fairly but to an overall fair hearing. In more recent times, European case-law has further developed a wide-ranging understanding of criminal proceedings. By departing from the accused-centred view of criminal trials, the Strasbourg judges have increasingly called for complex balances among conflicting interests, which are not only concerned with the public prosecutor and the private parties, but also with other individuals involved in criminal proceedings without being party to them, such as vulnerable witnesses, undercover agents, and so on.

The link between the principle of equality of arms and the right to be adjudicated by an impartial court, however, cannot be interpreted in such terms that this fundamental guarantee should only be fulfilled in the court proceedings. A relevant question, therefore, is whether and to what extent international human rights law also requires compliance with par condicio in the pre-trial inquiry. The examination of the delicate field of the right to confrontation with the accuser displays a significant difference in the approaches followed by the Strasbourg Court and domestic law. Without a doubt, the enshrinement of the general right to a public hearing by the European Convention entails that the trial provides the best conditions for the parties contributing to the

13 ECtHR, Fodale v. Italy, judgment of 1 June 2006, Appl. No. 70148/01, § 42. In this sense see already ECtHR, Laukkanen and Manninen v. Finland, judgment of 3 February 2004, Appl. No. 50230/99, § 34.

${ }^{14}$ In this sense cf. Trechsel. Human rights in criminal proceedings, p. 90. 
gathering of incriminating evidence. ${ }^{15}$ Strasbourg case-law, however, has never emphasised this approach to the extent that it deemed the trial confrontation to be the only solution compatible with the Convention. As was stressed in Asch v. Austria, ${ }^{16}$ confrontation in open court can be an undesirable result. For instance, in cases of serious organised crime, the prompt out-of-court collection of evidence by prosecutorial witnesses or co-defendants is usually of the utmost importance both for a clear reconstruction of complex situations and in order to avoid undue risks for the person examined. The Strasbourg judges have not explicitly clarified whether the Convention acknowledges the right to confrontation in the pre-trial phase. Yet the positive answer was implicit in Imbrioscia v. Switzerland, in which they ruled out a violation of the right to confrontation because neither the lawyer nor the defendant had asked to be present at the police questioning of a witness. ${ }^{17}$ Moreover, the Court's usual focus on the requirement that defendants be given a proper opportunity of confrontation at a later stage of the proceedings reveals a flexible approach, which does not make confrontation in a public trial a mandatory solution, provided, however, that the accused was granted an effective opportunity of confrontation. ${ }^{18}$

The Italian Constitution of 1947 did not provide an explicit acknowledgment of par condicio in court proceedings in general. Yet, along with the general principle of equal treatment of Article 3 of the Constitution, there was little doubt that the need for a fair balance of the rights and powers of the parties - particularly in the sensitive field of criminal proceedings, characterised in Italy by the prevailing role of the public prosecution office - was a necessary condition for the proper fulfilment of a number of constitutional safeguards, starting with the fundamental right to a defence and the presumption of innocence. Constitutional Amendment Law 2/1999, while enacting into the Constitution a set of

15 Ibid., pp. $305 \mathrm{f}$.

16

17 criminal proceedings, p. 309.

18

Rev. Bras. de Direito Processual Penal, Porto Alegre, vol. 4, n. 2, p. 559-603, mai.-ago. 2018. 
fair trial rights acknowledged by the European Convention, enshrined three basic features of all court proceedings, namely the right to be involved in judicial proceedings, the right to an impartial judge and the principle of equality of arms. A systematic examination of Article 111(2) of the Constitution surely excludes the possibility of interpreting these fundamental safeguards as unconnected from each other. It is hard to understand how the parties could be fairly heard in criminal proceedings without an independent and impartial judicial oversight that ensured full equality of arms. The need for systematic interpretation also deemphasized the need for a structuralist approach to the principle of contradictoire, ${ }^{19}$ which is strictly linked with the other constitutional rules regarding the fair trial rights of the accused. ${ }^{20}$ The effective exercise of the right to participate in criminal proceedings, in particular, requires defendants to be given proper information on the charges filed against them and to have enough time to prepare their defence. ${ }^{21}$ Furthermore, the accused's right to be confronted with incriminating witnesses ${ }^{22}$ lies at the core of the requirement of the parties' involvement in evidence-gathering and the principles of a fair fact-finding, to the point that defendants cannot be convicted on the basis of the statements given by individuals who voluntarily avoided any confrontation with the accused. ${ }^{23}$

As far as the right to confrontation is concerned, moreover, it is worth observing that Italian constitutional law departs from Strasbourg case-law by recognising the right to examine or have examined incriminating witnesses 'before a judge'. This provision, however, cannot be read in the sense that only confrontation in open court would be lawful for the purposes of decision-making, as Italian law provides a number of cases

19 Marzaduri. Commento all'art. 1 legge costituzionale 2/1999, p. 767.

20 The term 'accused' (accusato) is traditionally extraneous to Italian criminal procedural law, which usually relates to the person formally charged with a criminal offence as 'defendant' (imputato). Over recent years, however, the rising influence of international human rights law and EU law has led to the gradual spread of this new concept in Italian law. This poses unprecedented problems of compatibility with the national terminology, which in turn entails substantial implications on the scope of application of fundamental guarantees.

Art. 111(3) Const.

22 Ibid.

23 Art. 111(4) Const. 
in which the trial decision can (also) be based on evidence taken out of court. Thus, along with specific exceptions that can be justified in light of constitutional-law derogations from the principle of contradictoire, ${ }^{24}$ the Vassalli code allows the reading out of statements rendered by the accused in the pre-trial stages to the public prosecutor or the police acting upon delegation, statements that, even if inconsistent with the evidence given at trial, can be used against the defendant. ${ }^{25}$ On close examination, it is more than doubtful that such solutions are fully in line with the constitutional model of a fair trial. At any rate, the possibility of using evidence gathered by the investigative authorities out of court poses the delicate question of which safeguards are due to the person examined in light of the principle of equality of arms in the pre-trial stages, a question that does not only concern the questioning of suspects but also the prosecutorial or police hearing of other individuals, such as the victim, co-accused, vulnerable witnesses, and so on.

Certainly, the complex structure of criminal proceedings makes it by definition impossible for the public prosecution office and the private parties to be placed on an equal footing. Great differences exist between the public prosecutor and the defence. Even though prosecutors hold a number of rights in the manner of private parties, they can never have a private interest in fact-finding. Moreover, that the public prosecutor is called upon to carry out exhaustive investigations, collecting evidence both against and in favour of the suspect, ${ }^{26}$ still justifies the maintenance of coercive and decision-making powers which lie with the judiciary. This in turn poses the need to re-balance the relationship with private parties, particularly in the pre-trial inquiry.

It was surely not the intention of the drafters of the 1999 constitutional reform to disrupt this set-up by imposing a perfect equality of arms. Yet the enactment of the par condicio principle and the right to contradictoire in the same general provision on the essential requirements of all fair trials calls for a stronger relationship between these two fundamental guarantees than in the past. The achievement of a real equality of

\footnotetext{
24 Art. 111(5) Const.

25 Art. 503(5) CCP.

26 Arts. 326 and 358 CCP.
} 
arms does not only enable effective contradictoire among the parties, but should also require the enhancement of an independent oversight and the role of the judiciary in the pre-trial stages. ${ }^{27}$ This confirms that under Italian constitutional law too, the scope of the par condicio principle and the right to contradictoire cannot be circumscribed to court proceedings. One might argue that the principle of equality of arms should be recognized in an indirect manner in the preliminary phase, in that denial of defence rights would negatively affect the effective exercise of the right to contradictoire on an equal position at a later stage of the proceedings. ${ }^{28}$ Yet this explication would leave the defence unprotected in the prosecutorial and police inquiry, in which the imbalance between the law enforcement authorities and private parties reaches its highest tension.

The examination of the developments that have occurred over almost twenty years since the 1999 constitutional fair trial reform highlights the difficulties that the Italian criminal justice had to face to fulfil the constitutional principle of equality of arms and the right to an independent and impartial judge. In the following paragraphs, I shall examine the fragmentary evolution of Italian law, which not only reveals the inability of Italian legislation to depart from a somewhat paternalistic understanding of defence rights in the pre-trial inquiry, but also the inconsistencies that still characterise the role of the competent judge for procedural safeguards in this delicate phase.

\section{THE INITIATION OF THE PRE-TRIAL INQUIRY, INFORMATION RIGHTS AND THE NEED FOR INDEPENDENT OVERSIGHT OF THE PROSECUTORIAL INVESTIGATIONS}

The initiation of the pre-trial inquiry poses a number of difficult challenges from the viewpoint of a balanced distribution of powers. Notwithstanding that Italian procedural law, differently from that of other countries (e.g., Brazil), structures the preliminary investigations as a prosecutorial inquiry, the preliminary investigation has never lain

\footnotetext{
27 Marzaduri. Commento all'art. 1 legge costituzionale 2/1999, pp. $768 \mathrm{f}$.

${ }^{28}$ Ibid., p. 769.
} 
with the responsibility of the sole public prosecutor. To be sure, the 1988 code conceived of a centralised model of pre-trial inquiry, which started with the registration of notitia criminis by the competent prosecutor and allowed the police to investigate only by delegation, after prosecutors took over the leadership of the case. ${ }^{29}$ Nevertheless, under the original rules, the police could already gather notitiae criminis at their own initiative, ${ }^{30}$ and both the prosecutor and the police were empowered to conduct all the necessary investigations to enable the former to decide whether or not to indict defendants before the competent court. ${ }^{31}$ This centralised model of pre-trial inquiry, however, soon imploded on itself. A few years after the code's enactment, the 1992 antimafia legislative reform allowed the police to carry out autonomous investigations, ${ }^{32}$ which significantly altered the overall features of the pre-trial phase, enabling the police to conduct parallel inquiries to those headed by the competent prosecutor.

Despite these radical changes, the responsibility for the institution of the pre-trial inquiry is still generally in the hands of the public prosecutorial office, ${ }^{33}$ which raises several problems particularly in light of the European Convention and EU law. A first problem concerns the absence of a clear statutory deadline for the registration of notitia criminis, as Italian law only requires the public prosecutor to note the case 'immediately'. Although there is no independent oversight, eventual delays can, however, not jeopardise the person under investigation who, despite not having assumed the formal status of a 'suspect', cannot be questioned without the safeguards due to suspects. ${ }^{34}$ Yet the prosecutorial initiative of noting the alleged offence entails a number of relevant implications, starting with the information rights of the individuals concerned. To be sure, the annotation of the case does not in itself constitute a 'charge' in

\footnotetext{
29 Art. 348(1) CCP (1988 version).

30 Art. 330.

31 Art. 326 CCP.

32 Law Decree 306/1992, converted into Law 356/1992.

33 A significant exception is foreseen in the proceedings with fall within the competence of the justices of the peace, in which the pre-trial inquiry, as a general rule, lies with the responsibility of the police. See Arts 11 et seqq. of Legislative Decree 274/2000.

34 Art. 63(2) CCP.
} 
the terms of the European Convention, which requires the defendant to be informed (and to be kept informed) of the 'accusation'. ${ }^{35}$ Since the obligation to register the alleged offence fulfils the need to establish the time of formal initiation of criminal proceedings, the prosecutorial duty of annotation arises even if evidence against one or more individuals has not yet been collected. ${ }^{36}$ Moreover, it is apparent that, if the institution of a criminal inquiry entailed the duty of the competent authorities to immediately inform the individuals that might be involved in the criminal law action, this would frustrate the goals of the ongoing investigations. Therefore, the rules of Article 335 CCP, which do not require prosecutors starting a criminal investigation to provide information at their own initiative, are exempt from criticism. The need for information, however, arises when enough evidence is collected against one or more individuals, who must therefore be charged with a criminal offence ${ }^{37}$ by taking on the formal status of 'suspects'. ${ }^{38}$

The 1988 code provided for a radical solution in this regard, excluding any information until the defendant was brought to court. ${ }^{39}$ It is more than doubtful whether this harsh solution could be deemed in line with the constitutional-law right to an effective defence. ${ }^{40}$ It took several years, however, before Law 332/1995 acknowledged the right of both suspects and victims to receive information on the prosecutorial charge and its eventual modifications. Yet this legislative reform had considerable shortcomings, which raised several human rights concerns about the consistency of the new regulation with both constitutional law and the European Convention. Thus, the system introduced in 1995, which is largely still in force, does not require prosecutors to grant information ex officio, but only enables the individuals concerned to request information to the competent prosecutorial office.$^{41}$ Furthermore, the public

\footnotetext{
35 Art. 6(3)(a) ECHR.

36 Art. 335(1) CCP.

37 Marzaduri. Commento all'art. 1 legge costituzionale 2/1999, p. 782.

38 Art. 335(2) CCP.

39 Art. 335(3) CCP (1988 version).

40 Art. 24 Const.

41 Art. 335(3) CCP.
} 
prosecutor could also deny information if this might jeopardise the ongoing inquiry for a period no longer than three months. ${ }^{42}$ This is a very questionable solution, not only because the competent prosecutor can withhold the sought information on the ground of vague investigative needs, but also because the prosecutorial decision cannot be challenged before an independent authority.

The most difficult problem, however, is the choice of the legal classification of the offence, which also lies solely with the prosecutor noting the case. Without a doubt, the establishment of nomen juris is not a formal decision, but entails a number of delicate human rights implications. In particular, the 1995 legislative reform permitted the exclusion of information in cases of certain serious offences listed in Article 407(2)(a) CCP (kidnapping with the purpose of extortion, mafia-typed organised crime, terrorism, etc.). ${ }^{43}$ This solution, which is still in force despite the recent legislative implementation of Directive 2012/13/EU on information rights in criminal proceedings, ${ }^{44}$ provides a highly problematic presumptio juris et de jure. Thus, it is debatable that the abstract seriousness of the offence always entails risks for the ongoing investigation. ${ }^{45}$ Furthermore, it is clear that restrictions on the right to information cannot be justified in relation to the victim and the suspect in the same terms, as granting information to the victim does not entail similar risks to the ongoing inquiry. ${ }^{46}$

Moreover, the choice of nomen juris can have relevant consequences on the use of several investigative measures that seriously interfere with fundamental rights. Under Italian law, for example, wiretaps can only be ordered in relation to specific offences (Katalogtaten), ${ }^{47}$ as classified by the competent prosecutor while noting the case. Further implications, moreover, derive from the prosecutor's initial decision in the remand

42 Art. 335(3-bis) CCP.

43 Art. 335(3) CCP.

44 Legislative Decree 101/2014.

45 Marzaduri. Commento all'art. 1 legge costituzionale 2/1999, p. 779 fn. 110.

46 A recent legislative reform, however, ensured to the victim the right to request information on the ongoing inquiry the latest six months after lodging a complaint. See Art. 335(3-ter) CCP, enacted by Law 103/2017.

47 Art. 266 CCP. 
proceedings and the procedures regarding other restrictions on freedom of the individuals charged with some serious offences (especially mafia-type crimes). Thus, the Vassalli code, departing from the general understanding of pre-trial detention as extrema ratio, allows defendants to be remanded in custody solely on the basis of a suspicion of guilt. ${ }^{48}$ This set-up in turn exonerates both the prosecutor to demonstrate and the competent judge to ascertain the existence of specific risks for the ongoing procedure (risk of absconding, or tampering with evidence, or committing new serious crimes). In other words, this solution not

48 This controversial regulation was introduced by the aforementioned 1992 antimafia reform with regard to mafia-related crimes (mafia-type association, crimes committed using the typical conditions of mafia-type association and crimes of mafia abetting). Over more than two decades, the original rules have been amended several times. In 2009, a legislative reform carried out by Law-Decree 11/2009, converted into Law 38/2009, extended the scope of Article 275(3) CCP to the area of sexual offences and other serious crimes. This reform was largely countered by the Constitutional Court, which further narrowed the application of this exceptional mechanism. Ultimately, following the approach of constitutional case-law, Law 47/2015 distinguished the special rules on remand detention according to two groups of serious crimes. In case of the offences under Articles 270, 270-bis and 416-bis of the penal code (subversive association, criminal association aimed at national and international terrorism and at subverting democratic order, and mafia-related criminal association), pre-trial detention is to be applied if suspicion of guilt arises, unless it is proven that no risk exists to the ongoing inquiry. In relation to other serious crimes (murder, sexual crimes, etc.), the same mechanism applies, with the difference, however, that alternatives to custody can also be applied in case of attenuated risks to the proceedings.

At first glance, it appears that Italian law provides for proper balance among conflicting interests, allowing for the application of remand detention on the basis of a rebuttable presumption of dangerousness of defendants charged with these crimes. However, the code exonerates the judicial authority from assessing the real existence of any concrete risk to the ongoing inquiry. Thus, as a rule, the defendant must produce evidence in rebuttal. Furthermore, the possibility of overturning the presumption of dangerousness depends on very exigent proof on the part of the defence. That the assessment of suspicion of guilt provides the sole justification of remand detention raises serious human rights concerns especially in the cases of mafia-related criminal association and of sexual crimes, in which one can observe the widespread tendency of proving fumus delicti on the basis of dangerous inferences and presumptions. On the fact-finding in the field of mafia-typed crimes see the comprehensive analysis of Maggio. Prova e valutazione giudiziale dei comportamenti mafiosi, pp. $491 \mathrm{ff}$. 
only facilitates the onus probandi of the competent prosecutor, but also weakens the requirements of fact-finding, with evident repercussions on the right to freedom.

In sum, the prosecutor's unchallengeable choice of the legal classification of the alleged offence, without any independent oversight, can have a considerable influence on the decision-making powers of the competent judge. It is true that in the field of pre-trial coercive measures, Italian courts widely accept the possibility of the competent court for judicial review (riesame) changing the nomen juris chosen by the public prosecutor. ${ }^{49}$ Yet judicial review presupposes the appeal of the interested party, and the application of restrictions on freedom is purely accidental. De lege ferenda, the competent judge for the pre-trial inquiry should be able to scrutinise the appropriateness of the legal classification of the offence by the competent prosecutor; a good solution might be to require a judicial review of nomen juris at certain intervals. Of course, even such solutions would remain rather useless, if the competent judge were still precluded access to the prosecutorial file. The logic of non-inquiry, or limited inquiry, does not seem to be compatible with the need to ensure full protection of procedural safeguards in the investigative phase. There is no valid justification for withholding relevant information from the judicial authority, which should instead be given full knowledge of the evidence collected by the investigative authorities, regardless of whether or not access to the materials of the case if allowed to the defence.

\section{INTERFERENCE WITH FUNDAMENTAL RIGHTS, PROSECUTORIAL POWERS AND THE ROLE OF THE JUDICIARY IN THE PRE-TRIAL STAGES}

\subsection{PREMISE}

A highly problematic topic from the viewpoint of the present discussion concerns the use of coercive measures for the purposes of evidence-gathering in the pre-trial stages. The dynamics of the ordering of intrusive investigations, in particular, constitute a clear example of the

49 Negri. Fumus commissi delicti, p. 61. 
persistent inability of Italian legislation to provide a model of pre-trial inquiry that can fully satisfy the constitutional-law requirement of equality of arms throughout criminal proceedings. For the sake of clarity, I shall focus on three main issues, namely $a$ ) the increasing decision-making powers of the prosecutorial authority in ordering intrusive investigations, b) the role of the judiciary in the collection of usable evidence in open court, and finally $c$ ) participatory safeguards and the impartiality of the competent judge in the field of pre-trial detention and further restrictions on freedom.

\subsection{THE INCREASING DECISION-MAKING POWERS OF THE PUBLIC PROSECUTORIAL OFFICE IN ORDERING COERCIVE MEASURES}

Concerning the first issue, we have observed that the 1988 codification not only abolished the investigative magistrate but also drastically reduced the evidence-gathering tasks of public prosecutors, in that the information gathered by the investigative bodies, as a rule, could no longer be used in open court. The in-depth reforms carried out by the Vassalli code, however, did not suffice to eradicate all the coercive powers of prosecutorial authority, which under Italian law, as noted, still forms part of the judiciary. To a certain extent, it might be argued that the new criminal justice system, despite its strong adversarial approach, strengthened the pre-trial inquiry in comparison to the fascist codification, while maintaining some important decision-making powers on the part of the public prosecutorial office. There was a number of relevant examples. As a 'judicial authority', the public prosecutorial office was empowered to order physical inspections ${ }^{50}$ and home searches ${ }^{51}$ in the preliminary phase, and also in the exceptional cases in which the police could conduct searches without previous judicial authorisation, confirmation ought to be requested to the prosecutor. ${ }^{52}$ The competences of the prosecutorial authority were extended even to the area of free and secret (tele)communication, notwithstanding that Italian constitutional

\footnotetext{
50 Art. 244(2) CCP.

51 Art. 247(2-3) CCP.

52 Art. 352(4) CCP.
} 
law only allows restrictions on this fundamental right after judicial authorisation. ${ }^{53}$ Thus the 1988 code, while generally conditioning wiretaps on judicial authorisation, ${ }^{54}$ had already enabled the public prosecutor to order the interception of telecommunications in urgent cases, provided, however, that the competent judge validate the prosecutorial order. ${ }^{55}$

The years ahead not only led to the strengthening of the law enforcement and investigative powers of the police during the pre-trial inquiry, but also of the decision-making powers of the prosecutorial authority. The developments that have taken place in recent years confirm how deep the traditional understanding of the public prosecutorial office as an independent body of justice is still embedded in Italian criminal procedural law. A clear example was provided by Law 85/2009, through which Italy adhered to the 2005 Prüm Convention aimed at strengthening cross-border cooperation particularly in combating terrorism, cross-border crime and illegal migration. This legislation introduced new provisions with a view to establishing the conditions of taking specific forms of expert evidence requiring delicate medical checks, such as the sampling of hair or mucosa from the oral cavity for the purposes of DNA examination. ${ }^{56}$ The same legislative reform, moreover, laid down further rules aimed at governing the compulsory taking of biological samples in the pre-trial inquiry. Here also, as a general principle, judicial authorisation by the competent judge for the pre-trial inquiry is necessary in the absence of the consent of the interested person. ${ }^{57}$ Nevertheless, in urgent cases the competent prosecutor can order such medical surveys, which are, however, subject to subsequent judicial validation within short time-limits. ${ }^{58}$ The most worrisome case, furthermore, is where the police need such intrusive investigations during their autonomous inquiries for the purposes of the identity check of the suspect or other individuals who do not consent to the coercive sampling. In this case, the police cannot

\footnotetext{
53 Art. 15(2) Const.

54 Art. 267(1) CCP-Italy.

55 Art. 267(2) CCP-Italy

56 Art. 224-bis CCP.

57 Art. 359-bis(1) CCP.

58 Art. 359-bis(2) CCP.
} 
proceed without the authorisation of the public prosecutorial office, ${ }^{59}$ which here is therefore the competent body for ordering investigations that can severely affect the fundamental rights of the person subject to the expert examination.

More recently, we have witnessed a further enhancement of the prosecutorial decision-making powers in the field of interception of telecommunications. It has been noted that the 1988 code had already empowered the competent prosecutor to order wiretaps in urgent cases, provided that the competent judge for the pre-trial inquiry could validate the prosecutorial decree within short time-limits. Remarkably, the requirement of judicial validation is a necessary condition not only for continuing the ongoing interception but also for the admissibility of the information gathered. ${ }^{60}$ At the end of 2017, moreover, a wide-ranging legislative reform on interception of telecommunication ${ }^{61}$ enacted into the rules on wiretaps unprecedented provisions aimed at governing the use of modern eavesdropping devices, such as Trojan horses, to intercept private conversations among present people. ${ }^{62}$ It is noteworthy that in the proceedings for a number of serious crimes (criminal organisation, drug trafficking, etc.), prosecutors are also competent for ordering such intrusive forms of interception of communication in urgent cases, on condition that surveillance is validated by the judicial authority. ${ }^{63}$

\subsection{IN CAMERA PROCEDURES, RIGHT TO CONFRONTATION AND THE ROLE OF THE COMPETENT JUDGE FOR THE PRE-TRIAL INQUIRY IN THE GATHERING OF EVIDENCE FOR THE PURPOSES OF THE TRIAL DECISIONS}

Further imbalances can be observed in the field of the collection of evidence for the purposes of the trial decisions. In this regard also, the 1988 code, while dropping both the prosecutorial evidence-gathering and

59 Art. 349(2-bis) CCP.

60 Ibid.

61 Legislative Decree 2016/2017. For in-depth analysis of this reform see among others Giostra; Orlandi (coord.). Nuove norme in tema di intercettazioni.

62 Art. 267(1) CCP-Italy.

63 Art. 267(2-bis) CCP-Italy. 
the inquiry of an investigating judge, introduced a new judicial procedure in camera, aimed at taking evidence in the pre-trial phase with a view to the decision on the merits of the case. This procedure, called 'incidente probatorio', was mainly concerned with urgent evidence, that is, evidence that could not possibly be collected in open court. ${ }^{64}$ Furthermore, incidente probatorio did not necessarily pursue the aim of ensuring prosecutorial evidence, but also helped compensate suspects for the prevailing role of the public prosecutor at the pre-trial stage by granting them a powerful tool with a view to ensuring in advance useful information, which was to be inserted into the trial file. ${ }^{65}$ This aim was of the utmost importance at that time, mostly because of the lack of specific rules governing the carrying out of defence's investigations. The existence of multiple goals pursued by this mechanism was confirmed by the fact that the Vassalli code enabled both the prosecutor and the suspect (either personally or by means of his lawyer) to request judicial intervention.

At first glance, this procedure constituted a virtuous example of equal treatment of the parties in the new prosecutorial inquiry on several grounds. The code not only ensured the taking of evidence before an independent body - i.e., the competent judge for the pre-trial inquiry - but also required the application in incidente probatorio of the same rules governing the trial evidence-gathering. ${ }^{66}$ This in turn enhanced the suspect's right to confrontation, since, as a matter of principle, the taking of evidence could not be extended to issues concerned with individuals whose lawyers were not present ${ }^{67}$ and at trial, the information obtained, as a rule, could not be used against individuals not represented in court. ${ }^{68}$

These expectations, however, were largely frustrated. The restauration of rather inquisitorial practices by the 1992 antimafia legislation, while jeopardising the distinction between the prosecutorial and

64 It should be acknowledged, however, that the 1988 rules already provided for an important case of evidence-gathering unconnected from urgent reasons. Pursuant to Article 392(2) CCP, complex expert evidence should, as a rule, be taken in the pre-trial stage to avoid excessive congestion of the trial phase. Art. 431(1)(e) CCP. Art. 401(5) CCP.

67 Art. 401(6) CCP.

68 Art. 403 CCP. 
the trial file, strengthened the evidence-gathering powers of the public prosecutorial office in the pre-trial phase, which drastically reduced the prosecutor's interest in activating the court procedure of incidente probatorio. Moreover, though the 1999 constitutional fair trial reform paved the way for the establishment of par condicio also in the preliminary investigation, the lawmakers, by way of implementing the new constitutional-law principles, did not enhance this judicial procedure, but preferred to compensate for the overwhelming role of the public prosecutor by introducing a new set of investigative measures that the lawyers of private parties can carry out autonomously. ${ }^{69}$

On close examination, this procedure in camera has always ensured the impartiality of the judiciary and the fundamental right to confrontation to a somewhat formalistic extent. The first difficulties arise for the competent judge for the preliminary inquiry, since in the current criminal justice system, as noted, the taking of evidence at the pre-trial stages for the purposes of the trial decisions no longer falls within the ordinary tasks of the judicial authority. It is true that here the competent judge is not called upon to take evidence at his own initiative, but the judicial oversight of the gathering of evidence requested by the parties also constitutes a demanding challenge for the giudice per le indagini preliminari, who is normally kept in dark of the investigative strategy of the police and the prosecutorial authority. Indeed, though the code proclaims that incidente probatorio is governed by the same rules applicable to the trial evidence-gathering, it is difficult to imagine how a judge unaware of the prosecutorial strategy can truly check the exhaustiveness of questioning of witnesses or co-accused, and therefore, the need for additional questions, as allowed in all trial hearings. ${ }^{70}$

Moreover, it is questionable whether this procedure allows for private parties to have a fair opportunity to be involved in the gathering of incriminating evidence. Again, notwithstanding the formal extension of the rules applicable to the trial evidence-gathering, there are considerable differences from the way evidence is collected in open court. The main point of difference concerns the lack of information on the results of the

${ }^{69}$ Art. 391-bis et seqq. CCP.

70 Art. 506 CCP. 
prosecutorial and police investigations. Whereas at trial the parties are granted previous information on the oral evidence to be gathered, in the prosecutorial inquiry the defence normally has no access to the information obtained by the investigative bodies. The 1988 code did nothing to ensure information to the suspects involved in incidente probatorio. The problem arose a few years later, as the Constitutional Court pointed out the need for the public prosecutor to disclose previous statements given by the persons to be examined either at either the police or the prosecutor's office no later than the day of the court hearing. ${ }^{71}$ It was clearly a compromise solution, which left almost no time to prepare effective defence. Italian legislature, however, intervened only in $1996,{ }^{72}$ requiring disclosure from the prosecutors at the latest two days before the oral hearing. ${ }^{73}$ Although this solution marked an important step forward, its scope of application was restricted solely to the case in which oral evidence was to be taken and even in this case, the defence could only access the previous statements of the person to be examined, which was a rather accidental situation.

It is worth observing that these developments occurred in the aforementioned period of return to inquisitorial practices following the 1992 legislation, which dropped some of the main innovations brought about by the 1988 code to avoid the unconditional use of out-of-court evidence. To compensate for the strengthening of hearsay evidence, both constitutional case-law and the legislature introduced some important innovations, which contributed to the enhancement of incidente probatorio. In 1994, the Constitutional Court extended the scope of incidente probatorio to the intermediate phase ${ }^{74}$ which in turn altered the general dynamics of evidence-gathering in the pre-trial stages: thus, in the intermediate phase, unlike in the pre-trial inquiry, the accused has full access to the prosecutorial file. Three years later, Italian legislature uncoupled an important case of incidente probatorio from reasons of urgency, ${ }^{75}$ namely the hearing of co-defendants, no matter whether prosecuted in

71 Constitutional Court, judgment 74/1991.

72 Law 267/1997.

73 Art. 398(3) CCP.

74 Constitutional Court, 77/1994.

75 Art. 392(1)(c-d) CCP, as reformed by the Law 267/1997. 
the same or other proceedings, provided, however, that they were to be questioned on issues concerned with other persons. This reform clearly attempted to contrast the increasing use of prosecutorial evidence at trial by strengthening the taking of information by means of a court procedure in camera during the pre-trial inquiry. This result was of the utmost importance in the field of serious organised crimes, in which co-defendants can make a highly useful contribution to the ongoing investigation. Yet these developments confirmed the traditional tendency of Italian criminal justice to bring forward the fact-finding to the pre-trial phases. Since the 1997 reform, the examination of co-defendants can ordinarily take place out of court, at request of prosecutors, regardless of whether concrete grounds exist that justify the collection of evidence at the pre-trial stage.

Furthermore, the legislation issued in the midst of the 1990s did not only serve prosecutorial goals, but also marked a first important step in a process of in-depth changes in the structure of incidente probatorio, which ceased to be a tool (mainly) aimed at ensuring urgent evidence, becoming a mechanism of protection of the individuals involved in evidence-gathering. Remarkably, Law 66/1996 already enacted a new ground for incidente probatorio for the purposes of the examination of minors under 16 years old in proceedings for sexual offences. This important reform strengthened the voice of vulnerable individuals, regardless of whether they were injured by the offence under investigation or had witnessed it, ${ }^{76}$ so much so that the competent judge for the preliminary inquiry was enabled to take particular measures to gather the testimony of minors, requiring them to be heard outside the courtroom (e.g. in their place of living). The most relevant changes, however, took place after the 1999 fair trial constitutional reform, as the lawmakers amended most of the rules on the admission of out-of-court evidence by re-orienting them to the principle of contradictoire. Constitutional case-law strongly contributed to this evolution by declaring the regulation on incidente probatorio unconstitutional in that it did not account for cases involving vulnerable individuals, such as the victims of corruption ${ }^{77}$ and the mentally ill. ${ }^{78}$

\footnotetext{
76 Di Chiara. Incidente probatorio, p. 553.

77 Constitutional Court, judgment 262/1998.

78 Constitutional Court, judgment 63/2005.
} 
Another factor that has brought about functional changes in this special procedure was the increasing influence of international law, and particularly of international human rights case-law. It is noteworthy that in the same years in which the first developments occurred in the Italian law on the collection of pre-trial evidence, the Strasbourg Court made important steps toward the acknowledgment of a statute of victims and vulnerable witnesses. ${ }^{79}$ Over recent years, further legislative reforms, by way of domesticating important international and EU law instruments, have strengthened the ability of incidente probatorio to obtain evidence by vulnerable individuals. In 2013, the scope of this procedure was broadened by Law 119/2013, which implemented the 2011 Council of Europe Convention of Istanbul on preventing and combating violence against women and domestic violence, launching a reform aimed at enhancing the criminal law protection of women also by means of procedural tools. the legislative reform on gender-based violence. The following year, Law 24/2014, implementing the EU Directive on preventing and combating trafficking in human beings and protecting its victims,${ }^{80}$ extended the rules on pre-trial hearings to the judicial hearing of various vulnerable adults. ${ }^{81}$ A further enhancement of this procedure in camera was achieved by Legislative Decree 212/2015 implementing Directive 2012/29/EU on the victim's rights in criminal proceedings, which not only enabled the judicial hearing of vulnerable victims but also extended to incidente probatorio some protective forms of hearing laid down for their trial examination. ${ }^{82}$

To a great extent, these were positive results, which, enabling the examination of the aggrieved parties and vulnerable witnesses beyond urgent cases and through protective means, protected them against the risks deriving from police and prosecutorial questionings while strengthening the suspect's right to confrontation. However, these developments were not preceded by an in-depth reform of the general dynamics of incidente probatorio, which remained largely unchanged. As a consequence, the

\footnotetext{
79 ECtHR, Doorson v. The Netherlands, judgment of 26 March 1996, Appl. No. $20524 / 92$.

80 Directive 2011/36/EU.

81 Art. 398(5-ter) CCP.

82 Art. 398(5-quater) CCP.
} 
judicial hearing of victims and vulnerable witnesses is still subject to the request of either the public prosecutor or the defendant, since the victim is not yet entitled to apply for judicial intervention but can only ask the prosecutor to do so. ${ }^{83}$ Moreover, in spite of the legislative implementation of Directive 2012/13/EU, the defendant's information rights are still weak in the pre-trial stage, with the result that, as a general rule, suspects are called upon to take part in the gathering of incriminating evidence through incidente probatorio without a proper knowledge of the results of the prosecutorial inquiries. It is true that in all the specific cases in which incidente probatorio aims at hearing vulnerable victims or witnesses, the prosecutorial office is required to disclose all the information gathered by the investigative authorities. However, the indiscriminate disclosure of prosecutorial evidence, while enhancing defence rights and the tasks of the judiciary, can also entail human rights problems. It is apparent that, if public prosecutors were required to disclose the information also in the case in which evidence is collected at the accused's request, ${ }^{84}$ this might give rise to abuses and could largely frustrate the prosecutor's investigative strategy. Moreover, that in these particular cases the competent prosecutor must enable defendants to access the entire file of the pre-trial inquiry - and therefore also the evidence gathered in relation to other individuals - is certainly an excessive result, which can severely jeopardise the accused who is not affected by the sought evidence. Ultimately, it is questionable whether this solution, which was enacted by Law 66/1996 in relation to the examination of minors under 16 years old in proceedings for sexual offences, fits all the situations and the types of crimes listed in Article 392(1-bis) CCP.

\subsection{Pre-trial Restrictions on freedom, participatory safeguards and the IMPARTIALITY OF THE COMPETENT JUDGE}

Doubtless, the level of knowledge of the information gathered by the investigative authorities and the effectiveness of participatory safeguards constitute essential conditions of the proper fulfilment of the

\footnotetext{
83 Art. 394 CCP.

84 On this problem see Bargis. Commento all'art. 13 legge 66/1996, p. 504.
} 
constitutional-law requirements of contradictoire and equality of arms before an impartial judge where interference with fundamental rights is at stake. In the field of pre-trial measures (misure cautelari), the proceedings regarding restrictions on freedom, in particular, provide clear examples of a rather formalistic view of a fair trial, which entails severe implications on both judicial fact-finding and defence rights of the individuals concerned. This result is mainly due to the overall structure of the proceedings aimed at the application of remand and further coercive measures, which, albeit with certain exceptions,${ }^{85}$ still follow the traditional doctrine of inaudito reo decisions. As a consequence, individuals restricted in their most precious rights during the pre-trial inquiry (right to liberty, right to free movement, etc.) can only be heard after the judicial coercive order has been issued and, even worse, after the measure has been enforced. This judicial hearing aims at satisfying the fundamental right of the detained person to be brought before a judge, acknowledged by the European Convention ${ }^{86}$ and other international human rights charters, such as the International Covenant on Civil and Political Rights. ${ }^{87}$ The dynamics of these proceedings are similar to those of penal order procedures, with the difference, however, that a short-distance judicial hearing of the accused must always take place after the execution of the coercive measure on pain of loss of its validity. ${ }^{88}$

This mechanism raises two relevant questions from a human rights perspective, namely a) how the competent judge can impartially scrutinise the need for pre-trial coercion on the basis solely of the prosecutorial request and without hearing the defendant, and $b$ ) whether a subsequent judicial questioning suffices to ensure the accused a fair opportunity to be heard, while enabling the judicial authority to re-assess the justification of the measure applied in a fair and reliable

85 In particular, the accused must be previously examined when a coercive measure is to be applied in the hearing aimed at validating arrest and when a new period of detention is needed after a previous pre-trial detention has expired because of the failure to bring the accused to the judicial authority. Cf. respectively Arts. 294(1) and 302 CCP.

Art. 9(3) ICCPR.

Art. 294(4) CCP.

Rev. Bras. de Direito Processual Penal, Porto Alegre, vol. 4, n. 2, p. 559-603, mai.-ago. 2018. 
way. To be sure, unlike other European Constitutions,${ }^{89}$ the 1947 Italian Constitution did not require the judicial authority to hear the individuals subject to pre-trial detention, not only prior to the judicial order but also afterwards. It might be argued that this significant lacuna impinged on the further developments that occurred in Italian criminal justice. The drafters of the 1988 code of criminal procedure, while introducing a new set of comprehensive rules on pre-trial measures, left to public prosecutors a wide margin of discretion in selecting the information supporting their requests, which therefore impinged on the level of knowledge of both the defendant and the competent judge. Moreover, the possibility of the prosecutor withholding relevant evidence also frustrated the goals of judicial hearing, while preventing the suspect from setting up a proper defence strategy. Worse still, under the original prosecutors could conduct the first questioning of defendants remanded into custody or subject to further restrictions on freedom, and the lawyer's presence even at the judicial hearing was not mandatory, with the result that suspects had to face alone the same authority that requested the coercive measure.

This approach became inadequate already in the first years after the enactment of the new code. It took several years, however, before the legislature brought about some changes. The first important reform was carried out by Law 332/1995, which introduced two important innovations with a view to enhancing participatory rights and the impartiality of the judiciary: $a$ ) it imposed on prosecutors the duty to attach to their request all the information collected in favour of the suspect and eventual defensive statements already lodged; ${ }^{90}$ and $b$ ) it banned prosecutorial questioning before the individuals concerned had been heard by the judicial

89 For instance, the German Basic Law grants the individuals concerned the right to be informed of the grounds for arrest, a fundamental right that, moreover, entails the duty of the competent authority to hear them and allow them to raise objections and complaints against the arrest order. Cf. Art. 104(3) Basic Law. Remarkably, these guarantees also apply when the judicial authority orders pre-trial detention. This highlights that Germany enshrined at the constitutional level the right of detained individuals to obtain an independent assessment of the lawfulness of detention on the basis of their allegations and claims.

Art. 291(1) CCP. 
authority. ${ }^{91}$ Notwithstanding such positive achievements, this set-up was still largely unsatisfactory, mostly because of the weak defence safeguards both prior to decision-making and in the subsequent judicial hearing. Even after the 1995 reform, the decision on pre-trial measures was still issued inaudito reo. Moreover, it is clear that the notion of evidence 'in favour of the defendant' is by definition referential, which left to the prosecutorial authority much room for discretion in deciding what pieces of evidence must be attached to the request for a coercive measure. ${ }^{92}$ Depending on the decision made by the competent prosecutor, therefore, a considerable part of the prosecutorial and police investigations could be kept secret from the potential addressee of the sought measure. Most worryingly, the solution adopted enabled prosecutors to withhold relevant information also from the competent judge, who was not in a position to assess whether the prosecutorial decision to withhold information was justified by the need to avoid risks the ongoing inquiry and what implications it could have on the right to defence. In light of this, there was no independent oversight of the prosecutorial strategy and the protection of the right to information was entirely left to the unchallengeable decision of the competent prosecutor.

The negative repercussions of this set-up were magnified in the phase following the enforcement of coercive measures, mainly on two grounds. First, even after the 1995 reform, defendants were not to be given legal assistance in the subsequent judicial hearing. Second, withholding information from the defendant frustrated the possibility of challenging the lawfulness of coercive measures. In this regard, it should be noted that the Vassalli code provided for a special remedy against pre-trial detention and other restrictions on liberty, namely a judicial review (riesame) by a specialised court. ${ }^{93}$ The earlier case-law of the Supreme Court had ruled that this court could not annul the judicial order on the basis of evidence other than that attached by the prosecutor to the initial request or the information

91 Art. 294(6) CCP. It should be taken into account, however, that prosecutorial questionings were still allowed after provisional arrest and even in the hearing after the enforcement of remand detention, and the accused was not always assisted by a lawyer. See Constitutional Court, judgment 384/1996.

92 Supreme Court, 2nd Section, decision of 18 March 2008, Capri, in CED 239739. See Marzaduri. Commento all'art. 275, p. 179.

93 Art. 309 CCP. 
produced in the judicial review proceedings. ${ }^{94}$ To be sure, the 1995 reform required prosecutors to disclose subsequent information in favour of defendants, yet this requirement also had the same shortcomings of the new provision of Article 291(1) CCP. On close examination, the limitation of exculpatory evidence reflects an incorrect understanding of the right to a defence, which can be properly fulfilled if the defendant is ensured full knowledge of, and the possibility of contesting, incriminating evidence.

Subsequent legislation attempted to amend these deficiencies. The 2001 implementation of the constitutional fair trial reform enhanced the right to a defence by requiring the assistance of a lawyer in the judicial hearing, ${ }^{95}$ thus making the questioning conducted without a counsel void. In recent years, moreover, Italian lawmakers carried out a number of important reforms in the field of pre-trial measures. A first opportunity was provided by the 2014 legislative implementation of the aforementioned EU Directive 2012/13. The following year, Italian legislature brought about significant changes in the rules on pre-trial coercive measures. ${ }^{96}$ It is worth observing, however, that despite these important innovations some of the shortcomings highlighted hitherto have unfortunately remained unchanged, and to a certain extent have been aggravated. Notwithstanding the enhancement of information rights to comply with the requirements set forth by EU law, the rather paternalistic logic introduced by the 1995 reform is still in force, and the recent reform on interception of telecommunication has worsened this legislative set-up. Thus, while public prosecutors, as a general rule, must attach to their request for coercive measures the records of eavesdropping, a new provision enables them, "whenever necessary", to attach solely the "essential extracts" of the intercepted conversations. ${ }^{97}$ The obligation of disclosure only concerns exculpatory evidence, with all the limits deriving from the solution of 1995. Consequently, there is still a high risk that the ascertainment of the justification of the sought measure reflects the one-sided perspective of the prosecutorial authority.

94 Supreme Court, 1st Section, decision of 9 June 1995, Sanna, in CED 202460.

95 Art. 294(4) CCP.

96 Law $47 / 2015$.

97 Art. 291(1-ter) CCP. 
Further human rights concerns arise in relation to subsequent judicial hearing. Notwithstanding the enhancement of legal assistance by the 2001 reform, it can be doubted that this guarantee can still ensure full compensation for the failure to involve the defendant prior to the application of pre-trial measures, and can therefore properly fulfil the requirements set by the European Convention. To start with, it is apparent that the effectiveness of legal assistance in the judicial hearing largely depends on the possibility of defendants communicating with their lawyer. During the pre-trial inquiry, however, prosecutors can request the competent judge to postpone the interview between the detained suspects and their lawyer. ${ }^{98}$ It is true that the prosecutorial request must be justified by specific and exceptional grounds, but these rather vague statutory indications can give rise to abuses. From this it follows that defendants may happen to meet with (or even be introduced to) their lawyer only at the judicial hearing, which makes legal assistance, despite its mandatory nature, a purely formal guarantee. This situation is highly detrimental especially for defendants remanded into custody, who can remain up to five days without communication with their lawyer. Since this is the same time limit for the judicial authority to question them, ${ }^{99}$ defendants will inevitably loose any possibility of setting up a defensive strategy before the judicial hearing. ${ }^{100}$ The conditions for effective defence are further reduced when taking into account the fact that prosecutors can also request the moving forward of the remand hearing to within forty-eight hours from the enforcement of the coercive measure. ${ }^{101}$ If this result offers the advantage of moving forward the judicial guarantee, the postponement of the communications between the accused and his lawyer can have serious repercussions on the participatory rights and the right to freedom.

98 Art. 104(3) CCP. It is noteworthy, however, that Law 103/2017 restricted the scope of this provision to a list of serious offences, laid down in Art. 51(3-bis \& 3-quarter) CCP.

99 Art. 294(1) CCP.

100 The negative effects of the postponement are reduced in case of house arrest, further coercive means and control measures, since the hearing must here take place within ten days.

101 Art. 294(1-ter) CCP. 
Doubtless, this set-up reveals the scant attention paid by Italian law to the defence's contribution to the assessment of the lawfulness of coercive measures. A fair lawfulness test should require the fulfilment of specific qualitative conditions to enable the defendant to produce exculpatory evidence and to contest the prosecutorial information that supported the judicial order. Yet Italian law still has considerable backwardness in this regard, and notwithstanding some recent steps forward, it is debatable whether the current legislative solutions properly fulfil the requirements set by EU law. Thus, Directive 2013/48/EU expressly grants defendants legal assistance "before they are questioned by the police or by another law enforcement or judicial authority", ${ }^{102}$ while ensuring them the right to meet in private and communicate with the lawyer prior to questioning. ${ }^{103}$

Beyond the negative repercussions on the effectiveness of the right to a defence, it is clear that the degree of impartiality of the judicial authority also affects the fairness of the subsequent hearing. It is true that Italian courts rule out that the hearing conducted by a different judge is void. ${ }^{104}$ Nevertheless, the Vassalli code does not provide for any mechanism to prevent the defendant from being heard by the same judge who remanded him into custody or ordered another restriction on freedom against him on the basis of prosecutorial and police evidence. This makes it extremely difficult for the defence to obtain an impartial re-examination of the justification of the measure applied.

\section{THE RIGHT TO A DEFENCE AND THE PRINCIPLE OF EQUALITY OF ARMS IN THE PRE-TRIAL INQUIRY}

\subsection{THE CONSTITUTIONAL-LAW FRAMEWORK}

A last problematic issue, from the viewpoint of the principle of equality of arms in the pre-trial phase, concerns the way in which the individuals involved in criminal proceedings (particularly, the suspect)

\footnotetext{
102 Art. 3(2)(a) of Directive 2013/48/EU.

${ }^{103}$ Art. 3(3)(a) of Directive 2013/48/EU.

${ }^{104}$ Supreme Court, 3rd Section, decision of 4 December 2002, Caruso, in CED 223737.
} 
can exercise their right to a defence during the prosecutorial inquiry. Certainly, the new constitutional framework resulting from the 1999 fair trial reform provided the basis for a further enhancement of the defence's role and judicial oversight in evidence-gathering, beyond the possibility of taking part in the police and prosecutorial inquiries. The acknowledgment of the right of the accused to consent to the use of evidence taken out of court ${ }^{105}$ constitutes a clear example of this approach. Furthermore, it has been observed that the fundamental right to examine or have examined incriminating witnesses, recognised by the international human rights charters, was constitutionalised in a version that strengthens the need for confrontation "before the judge". ${ }^{106}$ Of course, this expression cannot be interpreted in such rigid terms that confrontation could only take place before the trial judges, since this would inevitably entail the unlawfulness of any decision based on evidence gathered out of court. Two aspects, however, distinguish the approach of Italian constitutional law from that followed by the European Convention and further developed by Strasbourg case-law. First, the Italian Constitution does not deem any confrontation sufficient to fulfil the defendants' right to contradictoire, instead requiring confrontation to take place, as a rule, in a court hearing with the direct involvement of the defence. Second, the constitutional-law arrangements exclude, as a matter of principle, confrontation being indirectly satisfied by means of questioning of incriminating witnesses by a judicial authority. ${ }^{107}$ Thus, the possibility of an investigative magistrate examining the accuser in favour of the defence does not seem to

105 Art. 111(5) Const. On the relevance of consent of the parties in fact-finding see among others Di Bitonto. Profili dispositivi dell'accertamento penale.

106 Art. 111(3) Const.

107 At first glance, the wording of Article 6(3)(d) ECHR reflects the alternative between self-defence and legal assistance, allowing for the examination of incriminating witnesses by the defence lawyer in the countries that do not enable defendants to cross-examine prosecutorial witnesses. On close examination, the drafters of the European Convention aimed at striking a compromise between two main forms of confrontation existent in the European countries, which broadly correspond to a form of cross-examination, typical of common-law countries, conducted by the parties and the continental tradition of witness's examination conducted by a third body (presiding judge of the tribunal, investigating magistrate, etc.). Cf. Trechsel. Human rights in criminal proceedings, p. 90. 
be in line with the Italian Constitution, since judges cannot clearly hear people before themselves.

Against this background, I shall focus on two main problems, which relate to $a$ ) legal assistance and the right to take part in the police and prosecutorial investigative activities, and $b$ ) the possibility of private parties charging their lawyers with the task of carrying out autonomous investigations in the interests of their clients in parallel with the prosecutor's inquiry.

\subsection{LEGAL ASSISTANCE AND THE RIGHT TO BE INVOLVED IN THE POLICE AND PROSECUTORIAL INQUIRIES}

Concerning the first issue, we saw that, in spite of its adversarial inspiration, the drafters of the 1988 codification maintained some important decision-making and coercive powers on the part of prosecutors as representatives of the judiciary, and to a certain extent enhanced the pre-trial inquiry in comparison to the Rocco code. To compensate for this approach, the Vassalli code, inheriting some of the solutions elaborated by constitutional case-law that had softened the strongly inquisitorial characteristics of the old istruzione, provided for various forms of involvement of suspects (and to a certain extent of the victim as well) in police and prosecutorial inquiries. Legal scholarship used to define them in terms of 'imperfect contradictoire', ${ }^{108}$ which can in turn have different features depending on the degree of participation. Yet, despite the clear attempt to enhance participatory rights in the pre-trial inquiry, it can be doubted whether this approach truly grants the individuals concerned a fair opportunity to be involved in the police and prosecutorial investigations. It is apparent that the absence of an impartial body and the dominant role of the investigative authorities cannot satisfy the constitutional requirements of fair evidence-gathering, based the principle of equality of arms. As long as prosecutors lead their investigations, the involvement of the defence will inevitably be secondary.

This is apparent in case of questioning by the investigative authorities. Clearly, the effectiveness of legal assistance largely depends on

${ }^{108}$ Cordero. Procedura penale, p. 891. 
whether and to what extent lawyers can actively participate in the hearing. In the case of police questionings, the lawyer can only be present. ${ }^{109}$ In the interrogation by the prosecutor or by the police upon delegation, the defence lawyer can instead make specific requests and observations to the competent authority. ${ }^{110}$ Notwithstanding this more active role, however, there is no formal means to avoid inadequate questioning for the suspect. To a certain extent, moreover, the assistance of a lawyer can rebound like a boomerang, since the statements rendered by suspects to the public prosecutor or the police upon delegation, if inconsistent with the evidence rendered in open court, can be read out at trial and used as incriminating evidence against them. ${ }^{111}$ Worse still, out-court-statements of defendants can be admitted at trial if they either do not consent to the trial examination or are not present in court. ${ }^{112}$ Yet, there are considerable differences between these two situations. Whereas the former reflects a clear defensive choice, the latter is a neutral situation, which neither expresses the accused's decision to waive his right to take part in criminal proceedings nor can per se make the out-of-court statements more reliable. In 2014, an important legislative reform - issued for the main purposes of aligning Italian legislation with the requirements set by EU law and particularly by Strasbourg case-law - abolished the old default proceedings (processo in contumacia), while allowing for the institution of proceedings in absentia under new conditions. Since these conditions do not still necessarily presuppose the accused's knowledge of the court proceedings, the possibility of using against absent defendants the statements given to the investigative authorities in the pre-trial phase raises serious human rights concerns, as it largely frustrates the general freedom of the accused to decide whether or not to be questioned at trial. ${ }^{113}$

The most elaborate form of involvement of private parties in prosecutorial inquiries in the pre-trial phase concerns the surveys conducted by technical advisors appointed by the prosecutor. In urgent cases,

\footnotetext{
109 Art. 350(3) CCP.

110 Art. 364(7) CCP.

111 Art. 503(5) CCP.

112 Art. 513(1) CCP.

113 Art. 503(1) CCP.
} 
prosecutors must follow a special procedure, which allows for the suspect not only to involve his lawyer but also to appoint a technical advisor of his own choosing. ${ }^{114}$ Even though technical and legal assistance allows for the individuals concerned to actively participate in the appointment of the technical investigation, the conducting of this survey, however, still remains in the hands of the public prosecutor without any intervention of an independent authority. Here also, moreover, the (potential) involvement of private parties can backfire, as the results of the technical survey conducted by the prosecutor's advisor will be included into the trial file as 'non-repeatable evidence', regardless of whether or not private parties had a fair opportunity to contribute to the prosecutorial investigation. ${ }^{115}$

In specific cases, Italian law recognises to individuals other than the suspect some participatory safeguards in the police and prosecutorial investigations. The rules on non-repeatable technical surveys conducted by prosecutor's advisors, for example, extend to the victim the same guarantees acknowledged to the suspect. ${ }^{116}$ A number of legislative reforms issued over more than twenty-five years has strengthened defence rights of some types of informants in particular cases of police or prosecutorial questioning in the pre-trial inquiry. Yet these reforms reflected a one-sided view of questioning, which does not take into due account the need for complex balance among conflicting interests in light of an overall understanding of criminal proceedings.

A clear example is provided by questioning of co-defendants. The 1992 antimafia legislation also empowered the police to question co-defendants at their own initiative, co-defendants who, unlike other informants, had to be assisted by a lawyer. ${ }^{117}$ It was an investigative power of no little importance, taking into account the relevance, especially for the purposes of proceedings regarding mafia-type crimes, of the information given by persons available for collaboration with the authorities. Almost ten years later, Law 63/2001 introduced an unprecedented form of witness testimony for co-defendants assisted by a lawyer (testimonianza assistita),

\footnotetext{
114 Art. 360 CCP.

115 See Article 360(5) in conjunction with Article 431 CCP.

116 Art. 360(1) CCP.

117 Art. 351(1-bis) CCP.
} 
reserved to the individuals prosecuted in same or in other proceedings who consent to give evidence against other persons. ${ }^{118}$ Remarkably, this testimony also was not limited to the trial inquiry, as the same legislation enabled both the police and prosecutors to question co-defendants pursuant to the new rules. ${ }^{119}$ This co-defendant's witness testimony enables a change of procedural status, which entails relevant consequences for the person examined. In particular, if the co-accused is ensured a full right to silence in normal cases, the scope of this right is generally restricted to the privilege against self-incrimination if he is available to give evidence on issues concerned with other people. Moreover, legal assistance can turn out to be a purely formal guarantee, since co-defendants are called upon to decide whether to give evidence on issues not exclusively concerned with their position without receiving clear information on the addressee of their statements. Worse still, the co-accused does not know in advance which questions the investigative authorities will put them. De lege ferenda, co-defendants should be properly informed before deciding whether to take on the role of special witnesses under Article 197-bis CCP. In other words, the different procedural status should be the consequence of the informed decision to answer questions directly concerned with other individuals, and to properly ensure this result, co-defendants, a good solution would be to allow for waiver of the right to silence only before a judge. ${ }^{120}$

More recently, Italian legislature strengthened participatory rights of other individuals in case of police and prosecutorial questioning - in particular, minors, either as victims or witnesses of certain serious crimes, as well as vulnerable witnesses. In 2012, a legislative reform, implementing the Lanzarote Convention on Protection of Children against Sexual Exploitation and Sexual Abuse, required prosecutors, while questioning minors (regardless of whether witnesses or victims) in case of particular serious crimes, to provide the assistance of an expert of child psychology or psychiatry. ${ }^{121}$ The aforementioned 2013 reform on gender-based

\footnotetext{
118 Art. 197-bis CCP. On this topic see among others Conti. L'imputato nel procedimento connesso.

${ }^{119}$ See respectively Arts. 351(1) and 362(1) CCP.

${ }^{120}$ In this sense cf. Tonini. Riforma del sistema probatorio, p. 272.

${ }^{121}$ Art. 362(1-bis) CCP, introduced by the Law 172/2012.
} 
violence later extended this requirement to the police questioning of minors. ${ }^{122}$ Finally, the 2015 legislative implementation of the EU Directive on victim's rights in criminal proceedings recognised the same safeguards to the victims (even adults) in case of particular vulnerability.

Notwithstanding these positive results, it is questionable whether Italian law properly meets the standards of protection set forth by international and particularly EU law, which requires Member States to provide vulnerable victims not only with specialist support but also with legal assistance. ${ }^{123}$ Unlike co-defendants, the aggrieved party has still no right to legal assistance if questioned by the police or the prosecutor, nor is legal assistance ensured to the minors questioned in cases of sexual crimes and other serious offences. A further shortcoming of this regulation, which can also be observed in relation to co-defendants, is the failure of Italian lawmakers to take into due account the accused's right to confrontation. Thus, all these reforms, despite enhancing participatory rights of the person examined, largely overlooked the problem of fulfilling the right of the addressee of incriminating evidence to be confronted with the accuser. Even in case of questioning of the co-accused examined as witnesses pursuant to Article 197-bis CCP, neither the police nor the prosecutor need summon the addressees of the co-accused's statements or their counsel. ${ }^{124}$ The need to avoid contacts with the suspect was expressly required in relation to the hearing of vulnerable witnesses. ${ }^{125}$ Yet, this solution cannot always be justified in all the types of police or prosecutorial questioning. Taking into consideration that the evidence rendered by minors or vulnerable witnesses can later be read out at trial, and under certain conditions can also be used against the accused, a better solution could be to require the investigative authority to set specific technological arrangements with a view to balancing the suspect's right to confrontation with the need to avoid negative consequences on the person examined.

\footnotetext{
122 Art. 351(1-ter) CCP.

${ }^{123}$ Recital no. 38 of Directive 2012/29/EU.

${ }^{124}$ Tonini. Riforma del sistema probatorio, p. 272.

125 Art. 351(1-ter) CCP.
} 


\subsection{THE RIGHT TO CARRY OUT AUTONOMOUS DEFENCE INVESTIGATIONS}

Notwithstanding the relevance attached to the principle of contradictoire, the 1988 code did not provide specific rules on the possibility of the lawyers of private parties carrying out autonomous investigations in parallel with the prosecutorial inquiry. Yet defence investigations have always existed. On close examination, this legislative set-up was no coincidence, but reflected the aforementioned choice of lawmakers to maintain the dominant role in the preliminary phase of the prosecutorial office, as an independent body of justice. Consequently, not only was the new competent judge for the pre-trial inquiry called upon to intervene only for specific procedural purposes and with a limited knowledge of the prosecutorial strategy, but furthermore defence lawyers could either conduct inquiries without a formal procedural status or request the public prosecutor to carry out specific investigations in the interests of their clients. Both alternatives were clearly unsatisfactory and negatively affected the equality of arms in the pre-trial stages. Thus, while the informal character of defence investigations impinged on the admissibility at trial of the evidence collected by counsels, the possibility of the investigative authorities conducting inquiries at the request of lawyers was subject to the prosecutor's discretion.

It was only Law 335/1995 that for the first time dealt with the problem of introducing a statute on defence investigations, but the innovations brought about by this reform were rather minimal. It took other five years before Italian legislature intervened again. Yet, the expectations of a proper fulfilment of the constitutional fair trial reform were largely frustrated. Whereas the admissibility of out-of-court evidence was considerably reduced, we have observed that several decision-making powers of the public prosecutor were maintained, and the role of the competent judge for procedural safeguards remained weak in the pre-trial inquiry. Italian lawmakers, therefore, walked a different road. It is noteworthy that one year before the implementation of the 1999 constitutional reform by the aforementioned Law 63/2001, another important reform - namely, Law 397/2000 - introduced an unprecedented regulation on the defence's investigations with a view to implementing the par condicio principle. ${ }^{126}$

${ }^{126}$ On defence investigations see Siracusano. Investigazioni difensive, pp. 496 ff. On close examination, although the heading of Law 63/2001 explicitly 
This legislative reform brought about a number of important innovations. In particular, it enabled the lawyers of private parties - i.e., not only of the suspect, but also of the victim or the damaged party to conduct specific formal investigations, such as the questioning of informants. By way of giving counsels formal investigative powers, Law $397 / 2000$ also dealt with the problem of admissibility and use of the information taken during private investigators and defence lawyers. To achieve this result, the reform introduced two relevant provisions: $a$ ) it allowed defence lawyers to have an official file set up at the office of the competent judge for the pre-trial inquiry, ${ }^{127}$ and $b$ ) it extended to the results of the lawyer's investigations the rules governing the reading out and use at trial of the evidence gathered out of court by the police and the prosecutor, ${ }^{128}$ rules that Law 63/2001, as noted, later amended pursuant to the requirements set by the 1999 constitutional reform.

This legislation, which is largely still in force, made several steps forward in the road towards the enhancement of defence's investigations. Even so, however, it is more than doubtful that this set-up achieves an effective equality of arms in the prosecutorial inquiry. It would be misleading to think that the recognition of formal investigative powers and the extension of the conditions of use of prosecutorial evidence to the information gathered by counsels could be enough to counterbalance the overwhelming role of the investigative authorities in the pre-trial phase. To a great extent, the imbalance between public prosecutors and the individuals involved in their preliminary inquiries is due to social and economic differences among the parties. Furthermore, the investigative authorities hold coercive powers, which defence lawyers of course cannot use. For instance, not only potential witnesses but also defendants and co-accused can coercively be brought to the police station or the prosecutor's office for the purpose of questioning. Defence lawyers lack similar powers, and if informants summoned to be examined refuse to

related to the implementation of the 1999 constitutional reform, this result was therefore due to both these legislative instruments. For in-depth analysis of these two reforms cf. Nobili. Giusto processo e indagini difensive, pp. $5 \mathrm{ff}$.

127 Art. 391-octies CCP.

${ }^{128}$ Art. 391-decies CCP 
appear or to answer specific questions, the only possibility is to request either questioning by the competent prosecutor or a judicial hearing by means of incidente probatorio. ${ }^{129}$ Therefore, giving a formal status to the investigations of defence lawyers could only reach a formal degree of par condicio. It might also be argued that the legislative attempt to compensate for the imbalance between the defence and the investigative authorities turned out to frustrate the principle of contradictoire, enhancing the possibility for both the prosecutor and private parties to gather evidence prior to the trial autonomously.

Doubtless, another factor that considerably alters the trade-offs in the pre-trial inquiry is the different level of knowledge of the investigations carried out by other parties. It is true that the defence's investigations do not necessarily follow the course of the prosecutorial inquiry as Law 397/2000 recognised the possibility of private parties charging their lawyers with the task of carrying out preventive investigations, i.e., with a view to the possible initiation of criminal proceedings. ${ }^{130}$ Nevertheless, it is apparent that this possibility presupposes the suspect being aware of the initiation of the prosecutorial inquiry. In this regard, the 2014 legislative implementation of the EU Directive 2012/13 strengthened the information rights in the pre-trial inquiry by enacting a new provision into the rules on a tool already existing, i.e., the notice of the investigation (informazione di garanzia), which aims at informing both suspects and victims of the ongoing prosecutorial inquiry. Pursuant to this new provision, prosecutors must inform both suspects and victims that they can obtain information about the annotation of notitia criminis. ${ }^{131}$ However, since the rules on information on the charge have remained unchanged, it is doubtful that this innovation brought about positive results. Thus, information can still be denied in cases of serious offences and that prosecutors can withhold information on the charge without any judicial oversight. Furthermore, the 2014 Directive did not modify the general features of the notice of the investigation, which is only due where the investigative authorities decide to carry out investigations at

\footnotetext{
129 Art. 391-bis(10-11) CCP.

${ }^{130}$ Art. 391-nonies CCP.

131 Art. 369(1-bis) CCP.
} 
which the lawyer can be present. ${ }^{132}$ Therefore, the information safeguards of the individuals concerned - and as a consequence, the possibility of initiating defence investigations - largely depend on the strategy of prosecutors and the police.

To a certain extent, the different levels of information in the preliminary inquiry can also lead to unjustified imbalances in favour of private parties in the trial phase. This result is mostly due to the acknowledgment of the right to have an official file, which enables private parties to put exculpatory evidence at the disposal of the judicial authority without the need to forward it to the competent prosecutor or to request the investigative bodies to carry out inquiries in their favour. The main difference with the prosecutor's file is, however, that lawyers are not required to insert all the information available in their official file. This set-up can not only alter the trade-offs in the distribution of powers among the parties but also frustrate the tasks of trial judges, making it impossible for both the fact-finders to verify the information available to the defence at a certain stage of the proceedings. This issue is of the utmost importance for the purposes of the admission of out-of-court evidence that become unavailable at trial because of unpredictable circumstances. ${ }^{133}$

An in-depth reflection on the potentials of the link among the equality of arms, the principle of contradictoire and the guarantee of judicial oversight should lead the Italian legislature to examine the advantages of alternative solutions. A proper solution might be to enhance jus postulandi of private parties, particularly in case of interference with fundamental rights. Thus, except in the case of access to private places or areas not open to the public that can be requested by a lawyer, ${ }^{134}$ Law 397/2000 failed to amend the rules on other intrusive investigative measures, such as wiretaps, which can still be ordered solely upon request of the competent prosecutor. The main concern that prevented the legislature from reforming this set-up was the fear that acknowledging to private parties the right to request a judicial order authorising the use of coercive measures could lead to worse results than those of the old prosecutorial

\footnotetext{
132 Art. 369(1) CCP.

133 Art. 512 CCP.

134 Art. 391-septies CCP.
} 
inquiry, while entailing the risk of misuse. ${ }^{135}$ Yet, this concern was probably excessive, taking into account that in Italian criminal justice, the judicial authority is always required to give reasons when interference with fundamental rights is necessary.

\section{Concluding Remarks}

The analysis of the rules governing the prosecutorial inquiry displays a complex scenario, in which, despite the progressive enhancement of participatory safeguards of private parties, the overwhelming role of the investigative authorities does not set the necessary conditions for effective equality of arms among the parties, while largely frustrating the tasks of the judiciary. To a great extent, the maintenance of several decision-making and coercive powers of the public prosecutor still largely reflects the old conception of an independent body of justice, which is currently justified in light of the broad notion of judiciary under Italian law. Notwithstanding that the individuals involved in the prosecutorial inquiry - in particular, the suspect, as well as in specific contexts, the victim - are ensured participation in a number of police and prosecutorial investigations, legal assistance often lacks effectiveness. Furthermore, the possibility of defence lawyers conducting autonomous investigations, which has been acknowledged since 2000, has satisfied the fundamental requirement of par condicio only to a somewhat minimal extent. A number of relevant factors distinguish the defence investigations from the prosecutorial inquiry, which go far beyond the sphere of legal differences. In spite of the attempt to compensate for the dominant role of public prosecutors, the principle of contradictoire - the cornerstone of the Italian constitutional-law model of a fair trial - is therefore fulfilled in the pre-trial inquiry by means of separate investigations and evidence-gathering activities of the police and the prosecutor, on one side, and the private parties, on the other. Yet the absence of coercive powers of defence lawyers and especially the scant possibilities of requesting judicial intervention to

${ }^{135}$ Marzaduri. Commento all'art. 1 legge costituzionale 2/1999, p. 770. 
have investigative measures ordered in the favour of the individuals concerned accentuate the difference with the investigative bodies.

The imbalances among the parties, moreover, do not only negatively affect the principles of contradictoire and equality of arms, but in light of an overall view of the constitutional-law fair trial guarantees, also inevitably impinge on the effectiveness of the role of the judiciary. There can be little doubt that the weak defence rights in the police and prosecutorial inquiries, as well as the difficulties of lawyers in carrying out effective defence investigations, do not set the best conditions for a fair evidence-gathering with a view to the decisions that can be made during the prosecutorial phase. Although the use of intrusive investigations and coercive measures, in particular, calls for independent oversight, the judge's assessment is often based only on the information collected by the investigative authorities, as suspects may not even know the existence of an ongoing prosecutorial investigation. The maintenance of a number of interim procedures aimed at a decision inaudito reo (remand proceedings, procedure on the use of eavesdropping devices, etc.) radically excludes the defence's intervention prior to decision-making. Worse still, Italian law acknowledges to public prosecutors wide possibilities of hiding relevant information not only to the individuals concerned and their lawyers, but also to the competent judge, who is often therefore not in a position to rule in a truly impartial way. Certainly, this solution cannot be justified in a human rights-oriented model of criminal justice, and de lege ferenda, the enhancement of the tasks of competent judge for the pre-trial inquiry, who under Italian law is not an investigative magistrate but is called upon to ensure the proper fulfilment of procedural safeguards, appears to constitute today the best alternative to one-sided investigations and the dominant role of the investigative authorities.

\section{ReferenCe LIST}

BARGIS, Marta. Commento all'art. 13 legge 66/1996. La Legislazione penale, 1996, pp. 498 ff.

CHIAVARIO, Mario. Il pubblico ministero organo di giustizia? Rivista italiana di diritto e procedura penale, 1971, pp. $714 \mathrm{ff}$. 
CONTI, Carlotta. L'imputato nel procedimento connesso. Diritto al silenzio e obbligo di verità. Padova: Cedam, 2003.

CORDERO, Franco. Ideologie del processo penale. Milano: Giuffrè, 1966.

CORDERO, Franco. Procedura penale. 9th edn. Milano: Giuffrè, 2012.

DI BITONTO, Maria Luisa. Profili dispositivi dell'accertamento penale. Torino: Giappichelli, 2004.

DI CHIARA, Giuseppe. Incidente probatorio. Enciclopedia del diritto. VI Agg. Milano: Giuffrè, 2002, pp. 546 ff.

GIOSTRA, Glauco; ORLANDI, Renzo (coord.). Nuove norme in tema di intercettazioni. Tutela della riservatezza, garanzie difensive e nuove tecnologie informatiche. Torino: Giappichelli, 2018.

MAGGIO, Paola. Prova e valutazione giudiziale dei comportamenti mafiosi: i risvolti processuali. In: FIANDACA, Giovanni; VISCONTI, Costantino (coord.). Scenari di Mafia. Orizzonti criminologici e innovazioni normative. Torino: Giappichelli, 2010, pp. $491 \mathrm{ff}$.

MARZADURI, Enrico. Misure cautelari personali (princìpi generali e disciplina). Digesto delle discipline penalistiche, VIII vol. Torino: Utet, 1994, pp. 59 ff.

MARZADURI, Enrico. Commento all'art. 275. In: CHIAVARIO, Mario (coord.). Commento al nuovo codice di procedura penale. III Agg. Torino: Utet, 1998, pp. 162 ff.

MARZADURI, Enrico. Commento all'art. 1 legge costituzionale 2/1999. La Legislazione penale, 2000 , pp. $762 \mathrm{ff}$.

NEGRI, Daniele. Fumus commissi delicti. La prova per le fattispecie cautelari. Torino: Giappichelli, 2004.

NOBILI, Massimo. Giusto processo e indagini difensive: verso una nuova procedura penale? Diritto penale e processo, 2001, pp. $5 \mathrm{ff}$.

TONINI, Paolo. Riforma del sistema probatorio: un'attuazione parziale del "giusto processo". Diritto penale e processo, 2001, pp. $269 \mathrm{ff}$.

RUGGIERI, Francesca. La giurisdizione di garanzia nelle indagini preliminari. Milano: Giuffrè, 1996.

SIRACUSANO, Delfino. Istruzione del processo penale. Enciclopedia del diritto, XXIII vol. Milano: Giuffrè, 1973, pp. 166 ff.

SIRACUSANO, Fabrizio. Investigazioni difensive. Enciclopedia del diritto, Annali II-1. Milano: Giuffrè, 2008, pp. 496 ff. 


\section{Informações adicionais e declarações dos autores (integridade cientifica)}

Agradecimentos (acknowledgement): I am very grateful to Prof. Dr. Lorena Bachmaier Winter for giving me the opportunity of dealing with the problematic issue of participatory rights in the pre-trial inquiry of Italian criminal proceedings from the viewpoint of the equality of arms and the impartiality of the judiciary. A special thank you also goes to my colleague Prof. Dr. Serena Quattrocolo for all her advices and relevant suggestions. As always, of course I bear entire responsibility for any mistake or inconsistency that the reader might have found in the text.

Declaração de conflito de interesses (conflict of interest declaration): o autor confirma que não há conflitos de interesse na realização das pesquisas expostas e na redação deste artigo.

Declaração de autoria e especificação das contribuições (declaration of authorship): todas e somente as pessoas que atendem os requisitos de autoria deste artigo estão listadas como autores; todos os coautores se responsabilizam integralmente por este trabalho em sua totalidade.

Declaração de ineditismo e originalidade (declaration of originality): o autor assegura que o texto aqui publicado não foi divulgado anteriormente em outro meio e que futura republicação somente se realizará com a indicação expressa da referência desta publicação original; também atesta que não há plágio de terceiros ou autoplágio. 
Dados do processo editorial

(http://www.ibraspp.com.br/revista/index.php/RBDPP/about/editorialPolicies)

- Recebido em: 04/05/2018

- Controle preliminar e verificação de plágio:

Equipe editorial envolvida 05/05/2018

- Avaliação 1: 21/05/2018

- Avaliação 2: 23/05/2018

- Editor-chefe: 1 (VGV)

- Editoras-associadas: 2 (LBW e BC)

- Revisores: 2

- Decisão editorial preliminar: 23/05/2018

- Retorno rodada de correções: 28/05/2018

- Decisão editorial final: 29/05/2018

\section{COMO CITAR ESTE ARTIGO:}

RUGGERI, Stefano. Equality of arms, impartiality of the judiciary and the role of the parties in the pre-trial inquiry: the perspective of Italian criminal justice. Revista Brasileira de Direito Processual Penal, Porto Alegre, vol. 4, n. 2, p. 559-603, mai./ago. 2018. https://doi.org/10.22197/rbdpp.v4i2.161

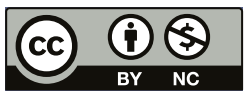

Esta obra está licenciada com uma Licença Creative Commons Atribuição-NãoComercial 4.0 Internacional. 